\title{
IDENTIFIKASI KESELAMATAN KERJA PADA PROSES PEMBUATAN PERAHU FIBERGLASS
}

\section{An Identification on Ocupational Safety in A Fiberglass Boat Building Process}

\author{
Oleh: \\ Prori Vitaliano Latief ${ }^{1^{*}}$, Budhi Hascaryo Iskandar ${ }^{2}$, Fis Purwangka ${ }^{2}$ \\ ${ }^{1}$ Mahasiswa Program Sarjana Departemen Pemanfaatan Sumberdaya Perikanan, FPIK, \\ Institut Pertanian Bogor \\ ${ }^{2}$ Staf Pengajar Departemen Pemanfaatan Sumberdaya Perikanan, FPIK, Institut Pertanian \\ Bogor \\ *Korespondensi: fis@psp-ipb.org
}

\begin{abstract}
ABSTRAK
Keselamatan kerja di setiap tempat kerja termasuk di sektor perbengkelan perlu diperhatikan untuk menekan serendah mungkin risiko kecelakaan kerja. Tujuan penelitian ini untuk mengidentifikasi secara jelas jenis bahaya pada aktivitas pembuatan perahu fiberglass. Identifikasi keselamatan kerja dilakukan dengan metode kasus melalui observasi langsung dan wawancara kepaada pembuatan perahu fiberglass. Identifikasi keselatan kerja dilakukan untuk setiap tahapan dalam proses pembuatan perahu fiberglass. Identifikasi terhadap proses pembuatan perahu fiberglass menunjukkan bahwa tahap pembuatan konstruksi kerangka merupakan tahap yang paling berisiko. Tingkat risikonya beragam dari ringan hingga fatal yang dapat menghilangkan nyawa seseorang. Analisis keselamatan kerja menunjukkan bahwa proses pembuatan perahu fiberglass memiliki tingkat risiko yang tinggi dilihat dari sisi keselamatan kerja.
\end{abstract}

Kata kunci: keselamatan kerja, perahu fiberglass, fiberglass.

\begin{abstract}
Ocupational safety in any workplace including in the workshop should be noted to reduce the risk of accidents as low as possible. The purpose of this research to clearly identify the types of hazards in fiberglass boat building activities. Idenfication of occupational safety was obtained through direct observation to the building process and interviewing the workers. The result showed that construction of the framework was the most risky phase. Risk levels vary from mild to fatal that might eliminate a person's life. Safety analysis showed that the process of making fiberglass boat has a high level of risk in terms of safety.
\end{abstract}

Keywords: Safety Works, Fiberglass Boats, Fiberglass.

\section{PENDAHULUAN}

Setiap pekerjaan pasti memiliki risiko tersendiri, pekerjaan terdiri dari beberapa aktivitas yang sebagiannya berhadapan langsung dengan alat-alat dan mesin yang kompleks dan dikendalikan oleh tenaga kerja itu sendiri. Dari sana dapat diperkirakan jenis bahaya yang mengancam jiwa, seperti tergelincir, bahaya elektrik.

Menurut Anton (1989) definisi kecelakaan kerja adalah sesuatu yang tidak terencana, tidak terkontrol, dan sesuatu hal yang tidak diperkirakan sebelumnya, sehingga mengganggu efektivitas kerja seseorang. Secara global, Lingga (2011) memperkirakan sekitar 337 juta kecelakaan kerja terjadi 
tiap tahunnya yang mengakibatkan sekitar 2,3 juta pekerja kehilangan nyawa. Menurut Suma'mur (1981) 80-85\% kecelakaan disebabkan oleh kelalaian atas kesalahan manusia sementara faktor teknis hanya 15-20\%. Kecelakaan umumnya diakibatkan karena berhubungan dengan sumber tenaga misalnya tenaga gerak mesin dan peralatan, kimia, panas, listrik di atas ambang dari tubuh atau struktur bangunan. Kemajuan teknologi juga telah merubah sifat dan bentuk pekerjaan. Banyak mesin-mesin, bahan maupun proses baru yang kita temui sebagai hasil kemajuan teknologi. Akan tetapi kemajuan teknologi juga membawa akibat sampingan yang merugikan bila tidak ditangani dengan baik, yaitu dalam bentuk bahaya-bahaya baru yang muncul seperti kecelakaan kerja, penyakit akibat kerja, pencemaran lingkungan dan sebagainya.

Pelaksanaan keselamatan kerja di tempat kerja termasuk di sektor perbengkelan diperlukan untuk menekan serendah mungkin risiko kecelakaan dan penyakit yang timbul akibat hubungan kerja. Dalam pelaksanaan pekerjaan sehari-hari, karyawan/pekerja akan terpapar dengan risiko bahaya di tempat kerjanya. Analisis keselamatan kerja diperlukan pada setiap tempat bekerja. Oleh sebab itu, dengan analisis ini dapat diketahui jenis cedera pekerja dan metode aman untuk menanggulangi kecelakaan yang lebih efektif.

Pembuatan perahu fiberglass merupakan salah satu pekerjaan yang berhubungan dengan alat dan bahan kimia yang berbahaya dan memerlukan penanganan yang baik untuk menghindari potensi kecelakaan. Pembuatan perahu fiberglass perlu mempertimbangkan aspek keselamatan yang dianggap kurang aman sehingga perlu diteliti. Tujuan penelitian ini untuk mengidentifikasi secara jelas jenis bahaya pada aktivitas pembuatan perahu fiberglass. Penelitian inimerupakan penelitian awal dari sudut pandang lingkup keselamatan kerja, oleh karena itu titik berat penelitian diberikan pada aspek identifikasi risiko.

\section{METODE PENELITIAN}

Penelitian dilakukan pada bulan Maret 2013, bertempat di ruang bengkel Bagian Kapal dan Transportasi Perikanan. Metode penelitian menggunakan metode studi kasus. Pengumpulan data primer dilakukan dengan cara pengamatan langsung pada pekerjaan dan lingkungan kerja, serta wawancara langsung dengan pekerja. Data pendukung diperoleh melalui penelusuran pustaka.

Proses pengolahan dan analisis data dilakukan di Laboratorium Keselamatan Kerja dan Observasi Bawah Air, Departemen Pemanfaatan Sumberdaya Perikanan, Fakultas Perikanan dan Ilmu Kelautan IPB, Bogor. Analisis data dilakukan secara deskriptif, dengan mengidentifikasi selengkap mungkin potensi bahaya dan pencegahan dalam tabel Job Safety Analysis.

\section{HASIL DAN PEMBAHASAN}

\section{Identifikasi Pekerjaan}

Berdasarkan penelitian yang dilakukan, pekerjaan pembuatan perahu fiberglass ini dibagi dalam beberapa tahapan besar yang mencakup keseluruhan tahapan pengerjaan dari awal hingga selesai. Tahapan pekerjaan pembuatan perahu fiberglass meliputi persiapan produksi yaitu segala hal yang diperlukan sebelum membuat perahu fiberglass seperti membuat desain perahu, menyediakan alat dan bahan yang diperlukan, mempersiapkan lokasi dan APD (Alat pelindung Diri). 
Tahapan pembuatan cetakan yaitu tahapan yang dilakukan setelah desain perahu yang inginkan didapatkan. Cetakan perlu didesain terlebih dahulu agar dapat membentuk badan perahu sesuai dengan yang diinginkan. Cetakan ini hanya dibuat sekali dan pembuatan badan perahu berikutnya menggunakan cetakan yang sudah ada. Tahapan pembuatan badan perahu perahu merupakan tahapan lanjutan setelah cetakan dibuat pembuatan badan perahu dimulai dari bagian bawah/dasar perahu mengikuti bentuk cetakan yang diinginkan dibuat dengan cara melapisi cetakan dengan mirror glaze terlebih dahulu sebelum melapisi dengan fiberglass agar badan perahu bisa terlepas dari cetakan dengan mudah. Tahapan selanjutnya adalah pembuatan konstruksi kerangka yang dimaksud kerangka disini adalah gading-gading dan galar-galar penghubung sisi-sisi perahu agar perahu lebih kokoh dengan cara menyambung dengan kayu dan polyurethane lalu dilapisi dengan fiberglass. Tahapan pengujian perahu merupakan tahapan penting untuk mengetahui kekurangan perahu, pengujian dilakukan di kolam dengan beban manusia. Tahapan terakhir yaitu finishing, Tahap ini untuk menyempurnakan perahu setelah diuji, merapikan bentuk perahu, dan melakukan pengecatan untuk memperindah perahu. Berikut merupakan bagan alir kegiatan pembuatan perahu fiberglass yang tersaji pada Gambar 1.

\section{Persiapan}

Tahapan satu dimulai dari pra persiapan yaitu kegiatan yang dilakukan sebelum melakukan tahapan persiapan yaitu toolbox meeting untuk memperjelas hal apa saja yang dilakukan dan tidak dilakukan serta bagian-bagian pekerjaan, dan mempersiapkan alat dan bahan yang akan digunakan pada tahap persiapan. Risiko pada tahapan ini termasuk bahan dan peralatan hilang karena seringkali benda tidak diletakkan kembali termasuk bahan dan peralatan tidak pada tempatnya. Risiko ini termasuk risiko menengah karena alat dan bahan yang digunakan berharga cukup mahal. Mitigasi yang disarankan yaitu menyediakan bahan dan alat cadangan untuk menghilangkan waktu yang terbuang jika alat atau bahan yang diperlukan tidak ada.

Selanjutnya membuat desain kapal, desain kapal itu sendiri terdiri dari rencana umum (general arrangement), dimensi utama, tabel offset, rencana garis (linesplan), parameter hidrostatis dan rencana konstruksi (construction plan). Risiko yang terjadi bisa dari setiap bagian sendiri-sendiri dan risiko ini mengakibatkan pekerjaan tertunda. Pekerjaan ini termasuk risiko ringan karena pekerjaan ini hanya bisa dilakukan oleh orang yang berkompeten di bidang desain kapal. Mitigasi yang disarankan yaitu pekerja diharapkan mengikuti pelatihan pembuatan desain kapal terlebih dahulu untuk mencegah risiko ini terjadi.

Tahapan selanjutnya adalah mendata jenis dan jumlah bahan yang diperlukan. Setelah diketahui desain kapal yang akan dibuat kemudian dibuat rencana jenis apa saja bahan yang diperlukan dan jumlah yang diperlukan. Pendataan ini dapat dikatakan penting karena risiko yang ditimbulkan akibat tidak merencanakan dengan baik salah satunya bahan yang diinginkan kurang atau tidak ada. Hal tersebut akan mengakibatkan penundaan pekerjaan karena membeli kembali bahan tersebut diperlukan waktu dan biaya yang tidak sedikit. Mitigasi yang disarankan untuk tahap ini yaitu pekerja memiliki kompeten yang baik dalam merencanakan pembelian bahan serta mengenal bahan yang diperlukan dengan baik. Tahap berikutnya adalah mendata jenis dan jumlah peralatan yang dibutuhkan memiliki risiko yang hampir sama namun perbedaannya terletak pada faktor tempat seperti perbengkelan biasanya sudah tersedia alat yang cukup memadai. Namun, diperlukan pengelompokan agar mudah dicari dan disimpan kembali.

Kesiapan area kerja dan APD (Alat pelindung Diri) sangat diperlukan untuk memperlancar proses produksi. Maksud dari mempersiapkan adalah merapikan lingkungan tempat produksi, meletakkan bahan dan peralatan di tempat yang telah disesuaikan agar pada saat produksi tidak terlalu banyak membuang waktu hanya untuk mencari alat atau bahan yang tercecer. Hal tersebut merupakan risiko jika tidak mempersiapkan area kerja dengan benar yaitu dapat menunda pekerjaan selanjutnya. APD atau alat pelindung diri sangat diperlukan untuk melaksanakan program K3 
(Kesehatan dan Keselamatan Kerja). APD secara umum terdiri atas helm pengaman (safety helmet), sepatu pelindung (safety shoes), sarung tangan (glove), penutup telinga (ear plug), kaca mata pengaman (safety glasses), masker (respirator), pelindung wajah (face shield), dan baju keselamatan (wearpack). APD sangat diperlukan untuk menekan laju kecelakaan kerja yang terjadi pada setiap pekerjaan berisiko fisik. Mitigasi yang disarankan untuk tahap ini yaitu pekerja mengerti jenis-jenis alat keselamatan yang diperlukan dan kondisi alat keselamatan tersebut.

Tahapan pasca persiapan merupakan tahapan dimana harus dilakukan melakukan evaluasi pada tahap persiapan. Risiko yang terdapat pada tahap ini adalah data hilang yang akan menghambat pekerjaan berikutnya. Mitigasi yang disarankan pada tahap ini adalah membuat data cadangan yang penting dan mencatat segala hal yang perlu dicatat pada tahap persiapan. Bagan alir proses persiapan produksi pembuatan perahu fiberglass yang tersaji pada Gambar 2.

\section{Pembuatan Cetakan}

Tahapan satu dimulai dari pra pembuatan cetakan, yaitu toolbox meeting untuk memperjelas hal apa saja yang dilakukan dan tidak dilakukan serta bagian-bagian pekerjaan, dan mempersiapkan alat dan bahan yang akan digunakan untuk mempersingkat waktu. Risiko pada tahapan ini termasuk bahan dan peralatan hilang karena seringkali bahan dan peralatan tidak diletakkan kembali pada tempatnya. Mitigasi yang disarankan yaitu menyediakan bahan dan alat cadangan untuk menyelamatkan waktu yang terbuang jika alat atau bahan yang diperlukan tidak ada.

Tahapan kedua adalah membuat desain cetakan. Cetakan harus dengan desain yang tepat agar hasil badan perahu sesuai dengan yang diinginkan. Kegiatan membuat cetakan ini memiliki risiko seperti salah cetakan yang termasuk risiko menengah karena membuat pekerjaan tertunda dan menghabiskan bahan serta waktu. Mitigasi yang disarankan pada tahap ini adalah pekerja yang membuat desain cetakan adalah pekerja yang berkompeten di bidang ini serta memiliki pengalaman dalam membuat cetakan fiberglass sebelumnya.

Tahapan ketiga adalah mempersiapkan bahan kayu yang terbagi dalam beberapa kegiatan yaitu mengukur kayu, memotong triplek, memotong balok kayu, melubangi kayu, meratakan kayu (smoothing), dan memasang kayu. Pada setiap kegiatan memiliki risiko tersendiri. Misalnya, penggunaan benda tajam akan mengakibatkan luka dari mulai tergores, tertusuk, dan terpotong. Selanjutnya jika tidak mengetahui cara menggunakan alat dengan benar, alat bisa membahayakan diri dan orang lain, seperti alat jatuh mengakibatkan tertimpa, dan peralatan rusak, dan yang lebih membahayakan jika terjadi hubungan arus pendek bisa mengakibatkan seseorang tersengat listrik atau terjadi kebakaran di area kerja. Begitupun pada tahap mempersiapkan bahan plat seng risiko yang terjadi pun hampir sama karena menggunakan alat yang hampir sama cara kerjanya. Mitigasi yang disarankan disini adalah menggunakan APD lengkap sesuai tugas yang dikerjakan. Pada tahap ini APD yang digunakan yaitu sarung tangan kain, safety glasses, wearpack dan safety shoes, lalu pekerja memiliki kompetensi yang baik, dan mengetahui POB penggunaan alat yang menjadi bagiannya. Perlu diperhatikan pula aspek kelistrikan berupa kabel-kabel dan stop kontak yang jauh dari lokasi bahan cair dan mudah terbakar.

Tahap selanjutnya adalah pemasangan bahan kayu dan plat seng agar membentuk cetakan yang diinginkan. Pada tahap ini hanya memerlukan paku dan palu untuk merangkai bahan kayu dan plat seng tersebut, sehingga risiko yang dapat terjadi pun tidak banyak seperti sebelumnya. Risiko pada tahap ini seperti penggunaan alat pukul dan benda tajam. Namun walaupun terkesan remeh apabila tidak dilakukan dengan benar akan mengakibatkan terpukul, tertusuk, tertimpa, dan peralatan rusak. Mitigasi yang disarankan pada tahap ini adalah pekerja memiliki kompetensi yang baik serta menggunakan APD yang sesuai pada tahap ini seperti sarung tangan kain, dan safety shoes.

Tahapan pasca pembuatan cetakan adalah tahap evaluasi pekerjaan. Pada tahap ini pekerja perlu mengetahui kendala yang diterima dan mendapatkan solusi secepat mungkin agar 
mempermudah pekerjaan selanjutnya. Pada tahap ini pekerja juga merapikan dan membersihkan area kerja agar tidak ada bahan dan alat yang hilang dan tercecer. Risiko yang terdapat pada tahap ini yaitu peralatan dan bahan hilang atau peralatan rusak. Mitigasi yang disarankan pada tahap ini adalah dibuatnya tempat khusus untuk meletakkan bahan dan alat pada tempat yang aman dan mudah dicari. Bagan alir proses pembuatan cetakan perahu fiberglass yang tersaji pada Gambar 3.

\section{Pembuatan Badan Perahu}

Tahapan pembuatan badan perahu dimulai dari pra pembuatan badan perahu yaitu aktivitas toolbox meeting untuk memperjelas hal apa saja yang akan dilakukan dan yang tidak dilakukan dan pembagian pekerjaan dengan jelas, dan mempersiapkan alat dan bahan yang diperlukan serta lokasi pembuatan badan perahu. Risiko pada tahapan ini termasuk bahan dan peralatan hilang karena seringkali bahan dan peralatan tidak diletakkan kembali pada tempatnya. Mitigasi yang disarankan yaitu menyediakan bahan dan alat cadangan untuk menyelamatkan waktu yang terbuang jika alat atau bahan yang diperlukan tidak ada.

Tahapan selanjutnya yaitu mempersiapkan bahan yang akan digunakan untuk proses pembuatan badan perahu perahu fiberglass. Pekerjaan yang ada pada tahap ini adalah menggunting woven roving dan mat sesuai ukuran dan jumlah yang diinginkan. Risiko yang dapat terjadi pada tahap menggunting mat dan woven roving adalah penggunaan benda tajam yaitu tergores dan terpotong. Ada risiko lain yang dapat terjadi karena bersentuhan langsung dengan bahan woven roving dan mat yaitu menyebabkan gatal pada kulit, perih pada mata. Setelah itu kita perlu melapisi bagian cetakan yang akan dilapisi fiberglass dengan mirror glaze terlebih dahulu agar mudah dilepas dari cetakan. Mitigasi disarankan untuk tahap ini adalah pekerja memiliki pengetahuan akan bahaya bahan yang digunakan atau pekerja memiliki kompeten yang baik dan menggunakan APD yang sesuai pada tahap ini yaitu sarung tangan kain, dan wearpack.

Sebelum mulai membuat fiberglass perlu membuat gelcoat terlebih dahulu. Gelcoat terbuat dari resin, talc, katalis, dan pigmen warna. Katalis adalah sejenis bahan yang befungsi sebagai penyebab reaksi kimia. Bahan ini sebagai katalisator dan akselerator pada proses pengeringan. Bahan katalis ini berisiko menyebabkan gelcoat berbahaya jika bersentuhan langsung dengan kulit karena bersifat korosif. Pada pembuatannya menggunakan alat bor yang dimodifikasi menjadi pengaduk agar mempersingkat waktu karena setelah bercampur dengan katalis hanya membutuhkan waktu singkat untuk mengeras. Penggunaan alat bor juga memiliki risiko seperti tertimpa alat, alat rusak, dan hubungan pendek arus listrik yang sangat berbahaya bagi pekerja. Mitigasi yang disarankan pada tahap ini adalah pekerja memiliki kompetensi yang baik dan menggunakan APD yang sesuai yaitu sarung tangan karet, wearpack, dan safety shoes serta lebih menjaga jalur aliran listrik.

Setelah melapisi dengan mirror glaze tahap selanjutnya adalah melapisi dengan fiberglass. Fiberglass dibuat dengan menyusun mat dengan woven roving secara berlapis dengan melapisi gelcoat pada setiap lapisannya. Lapisan pertama menggunakan mat lalu dilapisi dengan gelcoat, setelah itu woven roving dan dilapisi gelcoat. Lapisan woven roving memiliki serat yang lebih sulit dibasahi oleh resin, dengan kandungan resin yang lebih sedikit dibandingkan mat, maka laminasi serat woven roving ini memiliki ketahanan terhadap resapan air yang kurang baik. Kondisi ini dapat diperbaiki yaitu dengan laminasi serat woven roving dilapisi lagi dengan lapisan mat pada sisi luar yang memiliki kandungan resin polyster yang lumayan banyak. Risiko yang dapat terjadi pada tahap ini salah satunya adalah interaksi dengan bahan kimia dan debu fiberglass dan serat dapat menyebabkan iritasi dan gatal ketika digosok pada kulit. Hal ini dapat terjadi pada orang yang bekerja dengan fiberglass, dan itu terjadi terutama di lipatan kulit di sekitar pergelangan tangan, kerah dan ikat pinggang. Keringat dapat memperburuk kondisi tersebut. Selain risiko bahan kimia juga terdapat risiko fisik yaitu tergores fiberglass yang sudah mengeras. Mitigasi yang disarankan salah satunya pekerja harus memiliki kompetensi yang baik, menggunakan APD yang sesuai yaitu sarung tangan 
karet, masker, wearpack, dan safety shoes, dan diperlukan penjelasan bahaya bahan tersebut agar secara kebutuhan pekerja menggunakan alat keselamatan demi keselamatan jiwanya.

Fiberglass yang dibuat tidak mungkin langsung sempurna, pada tahap selanjutnya akan meratakan atau merapikan fiberglass. Meratakan atau merapikan fiberglass adalah kegiatan menghaluskan bagian yang masih kasar dan menghilangkan bagian yang tidak dibutuhkan dengan gerinda dan amplas. Risiko yang ada pada tahap ini adalah kontak langsung dengan bahan fiberglass atau terkena debu fiberglass di udara menyebabkan gatal pada kulit, mata, hidung dan tenggorokan. Ada kemungkinan bahwa serat menyebabkan kerusakan permanen pada paru-paru atau saluran pernapasan, atau meningkatkan kemungkinan kanker paru-paru. Serat debu yang terhirup dapat mengganggu saluran pernapasan, sehingga mengakibatkan batuk dan mengeluarkan lendir berlebihan. Kondisi ini disebut bronchitis. Mitigasi yang disarankan salah satunya pekerja harus memiliki kompetensi yang baik, pekerja menggunakan APD yang sesuai yaitu sarung tangan kain, masker, safety glasses, wearpack, dan safety shoes serta diperlukan penjelasan bahaya bahan tersebut agar secara kebutuhan pekerja menggunakan alat keselamatan demi keselamatan jiwanya.

Tahapan pasca pembuatan badan perahu adalah tahap evaluasi pekerjaan pada tahap pembuatan badan perahu pekerja perlu mengetahui kendala yang dihadapi dan mendapatkan solusi secepat mungkin agar mempermudah pekerjaan selanjutnya. Pada tahap ini dilakukan juga merapikan dan membersihkan area kerja agar tidak ada bahan dan alat yang hilang dan tercecer. Mitigasi yang disarankan pada tahap ini adalah dibuatnya tempat khusus peletakan bahan dan alat pada tempat yang aman dan mudah dicari. Bagan alir proses pembuatan badan perahu fiberglass yang tersaji pada Gambar 4.

\section{Pembuatan Konstruksi Kerangka}

Tahapan pembuatan konstruksi kerangka dimulai dari pra pembuatan konstruksi kerangka perahu dimana dilaksanakannya toolbox meeting dan pembagian jobdesk masing-masing pekerja. Risiko pada tahapan ini termasuk bahan dan peralatan hilang karena seringkali tidak diletakkan kembali pada tempatnya. Mitigasi yang disarankan yaitu menyediakan bahan dan alat cadangan untuk menyelamatkan waktu yang terbuang jika alat atau bahan yang diperlukan tidak ada.

Tahap berikutnya adalah mendesain cetakan. Berbeda dengan cetakan pada tahap sebelumnya, cetakan yang dimaksud disini adalah cetakan untuk memotong kayu dan polyurethane sesuai dengan bentuk yang diinginkan. Risiko yang ada pada tahap ini adalah jika bentuk yang didesain tidak sesuai dengan yang diinginkan akan memperlambat pekerjaan dan akan membuang banyak bahan. Mitigasi yang disarankan untuk tahap ini adalah pekerja yang bertugas memiliki kompetensi yang baik dalam pekerjaan mendesain cetakan.

Selanjutnya adalah mempersiapkan bahan kayu dan polyurethane, yaitu membuat kayu dan polyurethane berbentuk dan berukuran sesuai dengan yang diinginkan. Risiko yang ada pada tahap ini adalah penggunaan benda tajam bisa berakibat tergores, tertusuk, dan terpotong. Risiko lainnya adalah salah dalam hal operasional alat yang dapat berakibat jatuhnya alat atau rusaknya alat, dan terjadi hubungan pendek arus listrik yang dapat membahayakan jiwa pekerja. Mitigasi yang disarankan dalam tahap ini yaitu pekerja memiliki kompetensi yang baik, mengerti cara POB alat dengan baik, dan memakai APD yang sesuai yaitu sarung tangan kain, safety glasses, dan safety shoes.

Tahap selanjutnya yaitu memasang kayu dan polyurethane. Memasang atau merangkai bahan yang sudah dipersiapkan menjadi suatu konstruksi kerangka seperti galar-galar dan gading-gading. Risiko yang terdapat pada tahap ini adalah penggunaan benda tajam dan alat pemukul bisa berakibat seperti tertusuk, tergores dan tertimpa alat atau bahan. Mitigasi yang disarankan adalah pekerja memiliki kompetensi yang baik dan penggunaan APD yang sesuai yaitu sarung tangan kain, dan safety shoes. 
Tahap selanjutnya yaitu melapisi dengan fiberglass. Sudah dijelaskan sebelumnya cara pembuatan fiberglass sehingga menjadi lapisan yang kuat dan kokoh. Pertama membuat gelcoat lalu dilapisi mat dan woven roving. Risiko yang terdapat pada tahap ini adalah penggunaan bahan kimia yang dapat menyebabkan iritasi pada kulit, gatal dan jika terhirup akan menyebabkan sesak dan bronchitis. Mitigasi yang disarankan yaitu pekerja mempunyai kompetensi yang baik, mengerti bahaya setiap bahan kimia yang digunakan, dan memakai APD yang sesuai yaitu sarung tangan kain, safety glasses, wearpack, dan safety shoes.

Tahapan pasca pembuatan konstruksi kerangka adalah tahap evaluasi pekerjaan. Pada tahap pembuatan konstruksi kerangka, pekerja perlu mengetahui kendala yang dihadapi dan mendapatkan solusi secepat mungkin agar mempermudah pekerjaan selanjutnya. Pada tahap ini dilakukan juga merapikan dan membersihkan area kerja agar tidak ada bahan dan alat yang hilang dan tercecer. Mitigasi yang disarankan pada tahap ini adalah dibuatnya tempat khusus untuk meletakkan bahan dan alat pada tempat yang aman dan mudah dicari. Bagan alir proses pembuatan konstruksi kerangka perahu fiberglass yang tersaji pada Gambar 5. Tabel Job Safety Analysis proses pembuatan konstruksi kerangka perahu fiberglass terdapat pada Lampiran 1.

\section{Pengujian}

Tahap pertama yaitu tahap pra pengujian, pada tahap ini dilakukan toolbox meeting membahas perencanaan dan pembagian tugas dalam hal pengujian ini. Membahas cara memindahkan, alat bantu apa yang digunakan, dan mengadakan percobaan apa saja. Risiko yang dapat terjadi pada tahap pra pengujian ini adalah tidak adanya kolam yang siap digunakan untuk pengujian. Mitigasi yang disarankan yaitu dengan melakukan pengecekan lokasi terlebih dahulu sebelum memindahkan perahu.

Tahap selanjutnya adalah pemindahan perahu, aktivitas pemindahan ini memiliki risiko memindahkan benda berat yang dapat berakibat salah satunya tertimpa, keseleo, dan tergores. Risiko lainnya yaitu adanya bagian perahu yang masih kasar dapat menyebabkan gatal dan iritasi di kulit karena bahan fiberglass. Mitigasi yang disarankan dalam tahap ini adalah jumlah pekerja cukup dalam proses pengangkatan, mengetahui POB pemindahan benda berat, menggunakan alat bantu yang sesuai, dan menggunakan APD yang sesuai yaitu sarung tangan kain, wearpack, dan safety shoes.

Tahap pengujian kolam adalah saat dimana perahu diuji dengan beberapa faktor uji. Risiko yang terdapat dalam adalah saat bekerja diatas air salah satunya adalah tercebur, terhimpit, dan perahu terbentur. Mitigasi yang disarankan pada tahap ini adalah bekerja di area aman dari potensi tercebur, menggunakan metode pengujian yang tepat.

Tahapan pasca pengujian adalah tahap evaluasi pekerjaan, pekerja perlu mengetahui kendala yang diterima dan mendapatkan solusi secepat mungkin agar mempermudah pekerjaan selanjutnya. Pada tahap ini dilakukan juga merapikan dan membersihkan area kerja agar tidak ada bahan dan alat yang hilang dan tercecer. Mitigasi yang disarankan pada tahap ini adalah dibuatnya tempat khusus peletakan bahan dan alat ditempat yang aman dan mudah dicari. Bagan alir proses pengujian perahu fiberglass yang tersaji pada Gambar 6.

\section{Finishing}

Pada tahap finishing dimulai dengan pra finishing yaitu aktivitas toolbox meeting dan pembagian job desk masing-masing pekerja dan persiapan area kerja termasuk perlistrikan. Risiko pada tahapan ini termasuk bahan dan peralatan hilang karena seringkali bahan dan peralatan tidak diletakkan kembali pada tempatnya. Mitigasi yang disarankan yaitu menyediakan bahan dan alat cadangan untuk menyelamatkan waktu yang terbuang apabila alat atau bahan yang diperlukan tidak ada. 
Selanjutnya adalah pendempulan. Tahap ini dilakukan untuk memperbaiki kondisi badan perahu yang belum sesuai dengan keinginan. Dempul dibuat dengan bahan talc, resin, pigmen warna, dan katalis. Risiko yang dapat terjadi dalam tahap ini adalah penggunaan bahan kimia berbahaya yang dapat menyebabkan iritasi, gatal, dan keracunan. Mitigasi yang disarankan untuk tahap ini adalah pekerja memiliki kompetensi yang baik, mengetahui bahaya bahan yang digunakan, serta menggunakan APD yang sesuai yaitu sarung tangan karet, masker, dan wearpack.

Tahap selanjutnya adalah menghaluskan badan perahu. Setelah pendempulan masih perlu dihaluskan. Penghalusan badan perahu dilakukan dengan alat sander. Risiko yang dapat terjadi pada tahap ini adalah cara memegang alat yang tidak benar akan mengakibatkan alat terjatuh dan alat mengalami kerusakan. Risiko lainnya jika terjadi hubungan pendek arus listrik akan membahayakan pekerja di sekitar lokasi alat listrik. Mitigasi yang disarankan untuk tahap ini adalah pekerja memiliki kompetensi yang baik, mengetahui $\mathrm{POB}$ penggunaan alat, tidak lupa merapikan kelistrikan, serta menggunakan APD yang sesuai yaitu sarung tangan karet, masker, safety shoes dan wearpack.

Proses pengecatan dilakukan karena pada saat pembuatan gelcoat tidak menggunakan pigmen warna. Risiko yang dapat terjadi pada tahap ini adalah penggunaan bahan kimia yang dapat berakibat iritasi, gatal, dan keracunan. Mitigasi yang disarankan pada tahap ini adalah pekerja memiliki kompetensi yang baik, mengetahui bahaya bahan yang digunakan, dan menggunakan APD yang sesuai yaitu sarung tangan karet, masker, safety shoes dan wearpack.

Selanjutnya adalah pemasangan tali yang dilakukan dengan cara memberi lubang pada badan perahu untuk memasang tali. Risiko yang dapat terjadi yaitu penggunaan benda putar yang akan mengakibatkan tergores, tertusuk, dan tertimpa alat. Mitigasi yang disarankan pada tahap ini adalah pekerja memiliki kompetensi yang baik, mengetahui bahaya bahan yang digunakan, serta menggunakan APD yang sesuai yaitu sarung tangan kain, wearpack, dan safety shoes.

Tahapan pasca pembuatan konstruksi kerangka adalah tahap evaluasi pekerjaan. Pada tahap pembuatan konstruksi kerangka, pekerja perlu mengetahui kendala yang dihadapi dan mendapatkan solusi secepat mungkin agar mempermudah pekerjaan selanjutnya. Pada tahap ini dilakukan juga merapikan dan membersihkan area kerja agar tidak ada bahan dan alat yang hilang dan tercecer. Mitigasi yang disarankan pada tahap ini adalah dibuatnya tempat khusus untuk meletakkan bahan dan alat pada tempat yang aman dan mudah dicari. Bagan alir proses finishing perahu fiberglass yang tersaji pada Gambar 7. 
Berikut adalah bagan alir setiap tahapan kegiatan proses pembuatan perahu fiberglass.

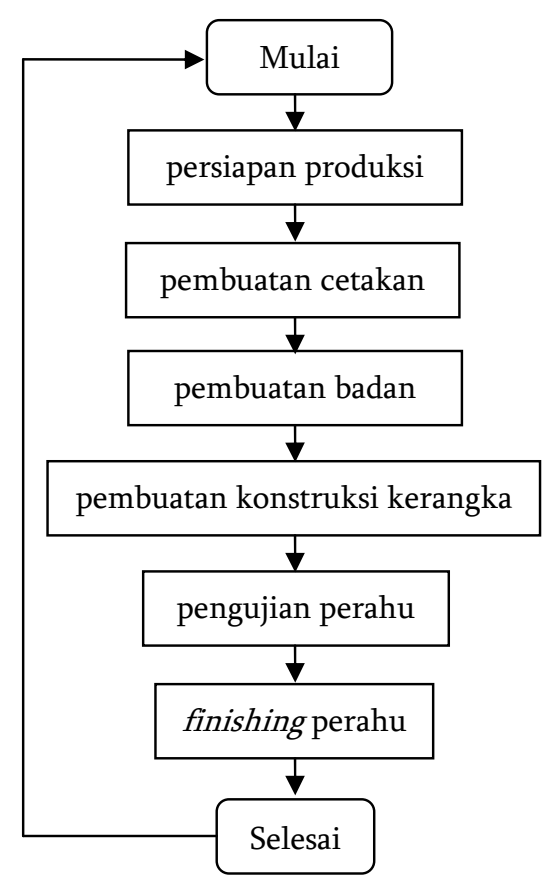

Gambar 1 Bagan alir kegiatan produksi pembuatan perahu fiberglass

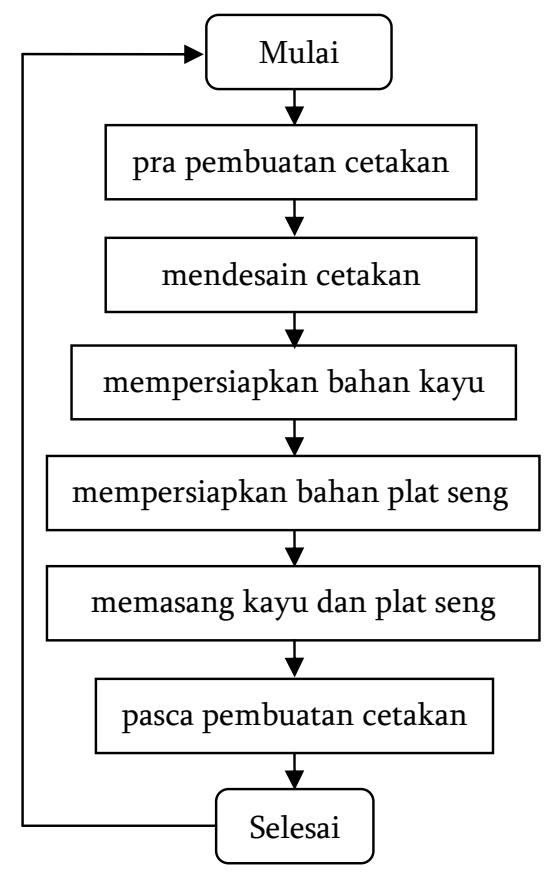

Gambar 3 Bagan alir kegiatan pembuatan cetakan

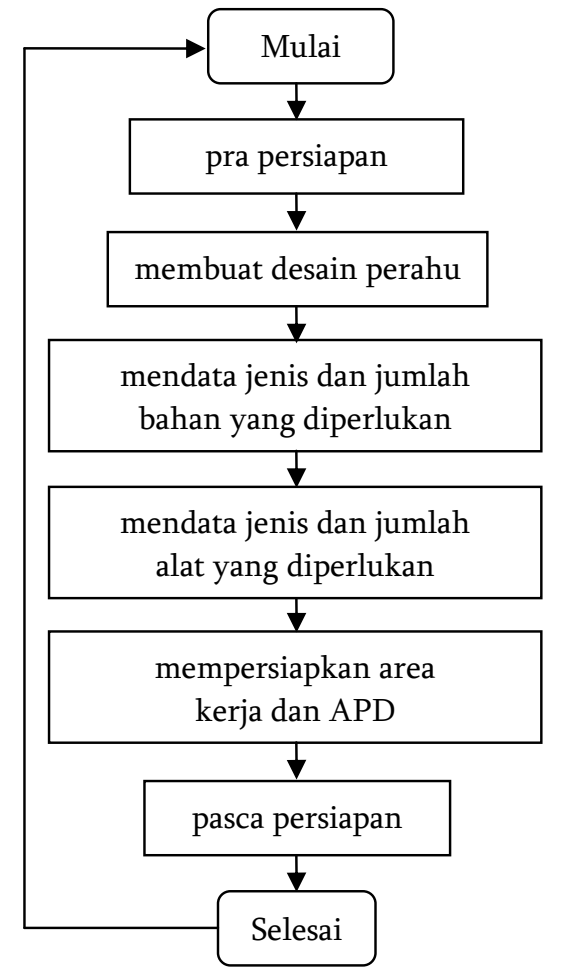

Gambar 2 Bagan Alir kegiatan Persiapan pembuatan perahu fiberglass

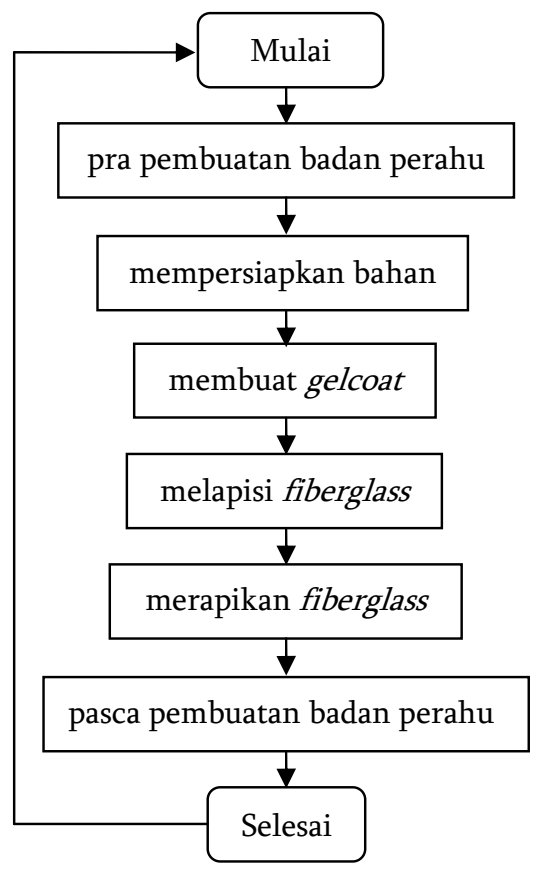

Gambar 4 Bagan alir kegiatan permbuatan badan perahu 

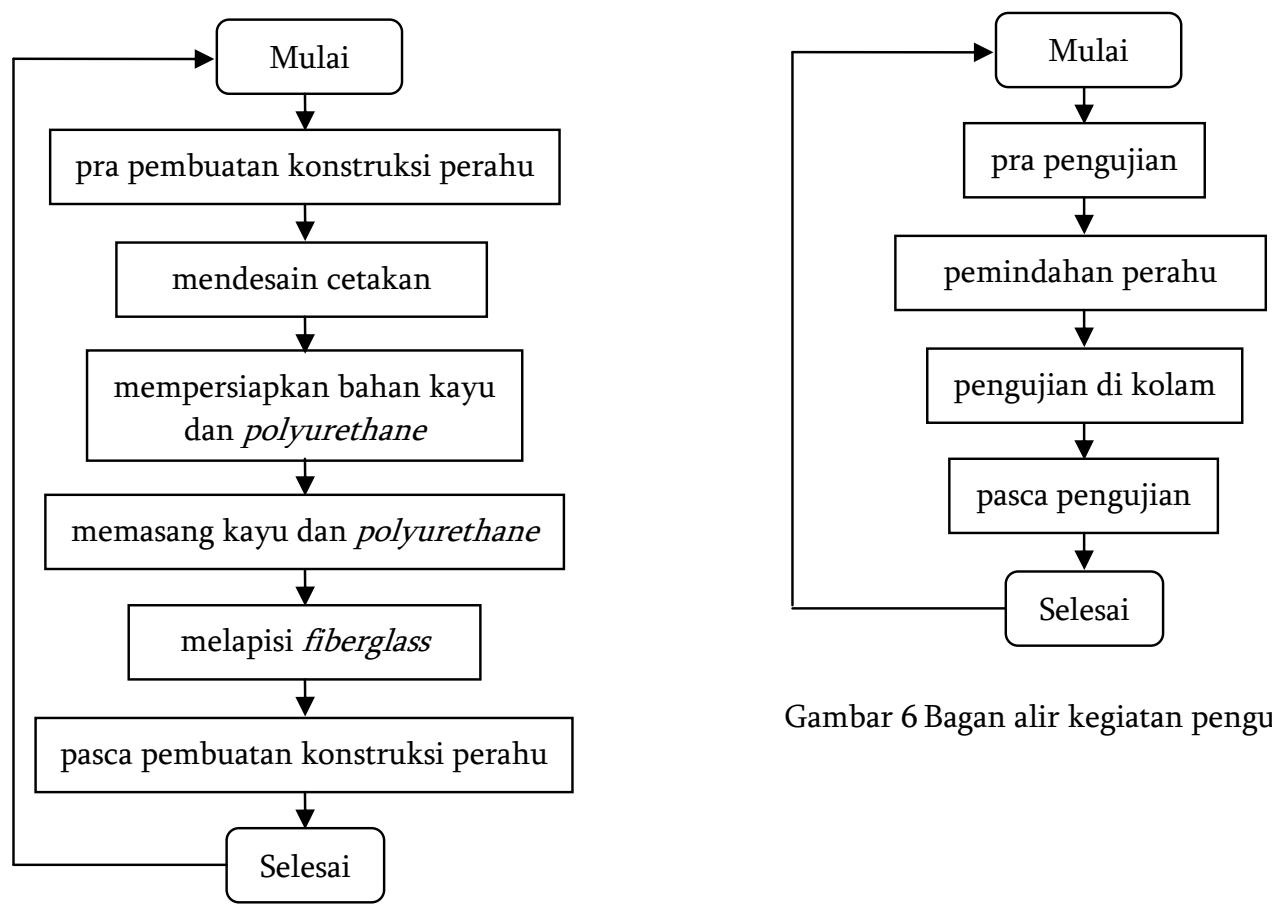

Gambar 6 Bagan alir kegiatan pengujian perahu

Gambar 5 Bagan alir kegiatan pembuatan konstruksi kerangka perahu

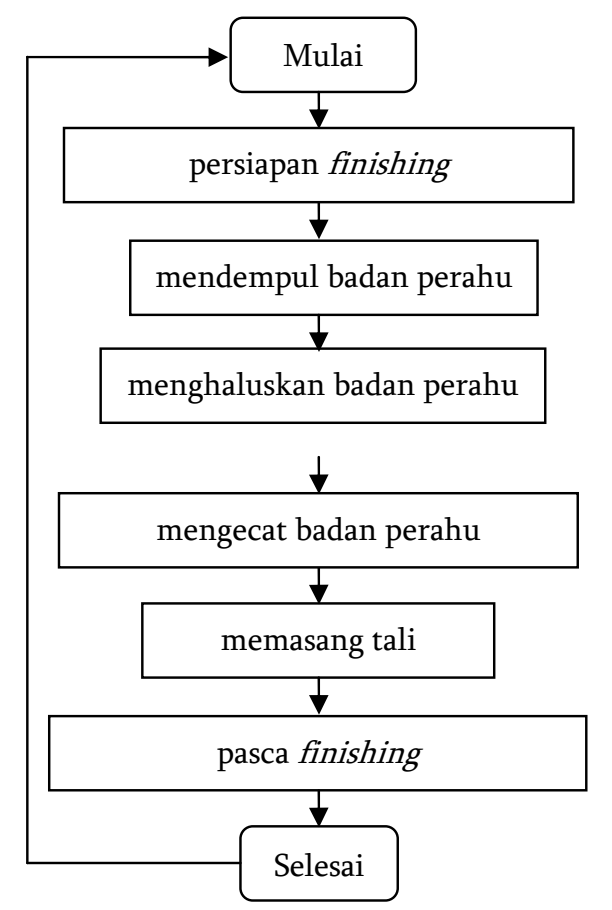

Gambar 7 Bagan alir kegiatan finishing perahu 


\section{KESIMPULAN DAN SARAN}

\section{Kesimpulan}

Identifikasi terhadap proses pembuatan perahu fiberglass menunjukkan bahwa tahap pembuatan konstruksi kerangka perahu merupakan tahap yang paling berisiko. Tingkat risikonya beragam mulai dari ringan seperti gatal, menengah seperti iritasi kulit, berat seperti terpotong, dan fatal seperti tersengat listrik yang dapat menghilangkan nyawa seseorang. Analisis keselamatan kerja menunjukkan bahwa proses pembuatan perahu fiberglass memiliki tingkat risiko yang tinggi dilihat dari sisi keselamatan kerja.

Saran

Risiko keselamatan kerja yang tinggi dapat diturunkan dengan menjalankan mitigasi dan pelaksanaan $\mathrm{POB}$ sesuai tahap pekerjaan pada proses pembuatan perahu tersebut.

\section{DAFTAR PUSTAKA}

Ahmad DF. 2010. Identifikasi Bahaya dan Upaya Pengendalian yang Dilakukan pada Pekerja Railing di PT. PP (PERSERO) Proyek Gedung Fakultas Kedokteran dan Ilmu Kesehatan Jakarta Tahun 2009. [Skripsi]. Jakarta (ID) Fakultas Kedokteran dan Ilmu Kesehatan. Hal 67.

Anton TJ. 1989. Occupational Safety and Health Management (2 ${ }^{\text {nd }}$ Edition). New York (US): McGrawhill.

Chao EL. 2002. Job Safety Analysis OSHA 3071. Occupational Safety and Health Administration: (US)

Lingga G. "Hari Keselamatan dan Kesehatan se-Dunia: Mencegah kecelakaan kerja melalui pelaksanaan manajemen risiko K3". http:// www.ilo.org/jakarta/info/public/pr/ WCMS_155174/lang--en/index.htm. (ID) Press release 26 April 2011 (diakses 4 Februari 2013).

Mulya A. 2008. Analisis dan Pengendalian Risiko Keselamatan Kerja dengan Metode Semi Kuantitatif pada Pekerja Pengelasan di Bengkel Pabrik PT. ANTAM Tbk UBP Emas Pongkor Bogor Tahun 2008. [Skirpsi]. Jakarta (ID): UIN Syarif Hidayatullah.

Lane R, Stanton N. \& Harisson, D. 2008. Hierarchical Task Analysis to Medication Administration Errors. Kingston Lane Uxbridge (UK): Departemen of Design and Information System Brunel University.

Lyons M, Adams S, Woloshynowych M. \& Vincent C. 2004. Human Relibility Analysis in Healthcare: A Review of Technique. International Journal of Risk \& Safety in Medicine, (UK) 16, 223-237.

Ridley J.2004. Kesehatan dan Keselamatan Kerja. Edisi Ketiga. Jakarta (ID): Erlangga. hal 45.

Suma'mur PK, Dr. 1981. Keselamatan Kerja \& Pencegahan Kecelakaan. Jakarta (ID) : CV Haji Masagung.

[CCOHS]. Canadian Centre of Occupational health and Safety.2008. Job Safety Analysis. (CA) http://www.ccohs.ca/oshanswers/ hsprograms/jobhaz. html\#tphp. (diakses 4 Februari 2013). 